\title{
IMPROVED NARRATIVE WRITING SKILLS BY APPLLYNG THE COOPERATIVE LEARNING MODEL CONCEPT SENTENCE TYPE WITH SERIES PICTURE MEDIA
}

\section{Linda Margiyan, Rukayah, Hadi Mulyono}

Universitas Sebelas Maret

lindamargiyani@gmail.com

\begin{tabular}{ll} 
Article History & Abstract \\
\cline { 1 - 3 } $\begin{array}{l}\text { accepted 09/07/2018 } \\
\text { approved 01/08/2018 }\end{array}$ & $\begin{array}{l}\text { The purpose of this research is to improve narrative writing } \\
\text { skill in third grade students of State Primary School of } \\
\text { Mangkuyudan 02 Surakarta through the application of } \\
\text { cooperative learning model of Concept Sentence type with } \\
\text { picture series media. The type of this research is classroom } \\
\text { Keywords }\end{array} \quad \begin{array}{l}\text { action research held in three cycles. The subject of this } \\
\text { research are teacher and } 27 \text { students in the third grade of } \\
\text { media picture series, } \\
\text { narrative writing skills }\end{array}$ \\
$\begin{array}{l}\text { State Primary School of Mangkuyudan 02 Surakarta in the } \\
\text { academic year 2017/2018. The data collecting by interview, } \\
\text { observation, test, and document review. The data validity } \\
\text { technique of this reseach is content validity, triangulation of } \\
\text { source and technique. The data analysis using descriptive } \\
\text { comparative technique and interactive analysis model Miles } \\
\text { Huberman. The conclusion of this research is cooperative } \\
\text { learning model Concept Sentence type with series picture } \\
\text { media can improve the writing narrative composition. }\end{array}$ \\
\hline
\end{tabular}

Social, Humanities, and Education Studies (SHEs): Conference Series

p-ISSN 2620-9284

https://jurnal.uns.ac.id/shes

e-ISSN 2620-9292 


\section{PENDAHULUAN}

Pembelajaran Bahasa Indonesia berperan penting dalam membentuk kebiasaan, kemampuan, dan sikap siswa untuk tahap perkembangan selanjutnya. Tujuan pembelajaran Bahasa Indonesia di sekolah dasar sesuai dengan Permendikbud Nomor 21 Tahun 2016 adalah sebagai berikut: (1) memiliki kepedulian, rasa percaya diri, kedisiplinan, dan tanggungjawab dalam pemanfaatan Bahasa Indonesia; (2) mengenal konteks budaya dan konteks sosial, satuan kebahasaan, serta unsur pralinguistik dalam penyajian teks; (3) mengenal bentuk dan ciri teks laporan sederhana; dan (4) menyajikan secara lisan dan tulis berbagai teks sederhana. Terdapat empat keterampilan berbahasa yang harus dikuasai peserta didik, yaitu: (1) keterampilan menyimak; (2) keterampilan berbicara; (3) keterampilan membaca; dan (4) keterampilan menulis.

Keterampilan menulis merupakan salah satu keterampilan berbahasa yang sering digunakan untuk menyampaikan informasi. Penyampaian informasi bisa melalui media cetak maupun media elektronik. Hal tersebut sesuai dengan pendapat Dalman (2015: 3) yang menyatakan bahwa menulis merupakan suatu kegiatan komunikasi berupa penyampaian pesan (informasi) secara tertulis kepada pihak lain dengan menggunakan bahasa tulis sebagai alat atau medianya. Hal ini diperkuat oleh pendapat Suparno dan Yunus (2008: 3) yang menyatakan bahwa menulis sebagai suatu kegiatan penyampaian pesan (komunikasi) dengan menggunakan bahasa tulis sebagai alat atau medianya.

Di sekolah dasar, terutama di kelas III terdapat Kompetensi Dasar menulis karangan sederhana berdasarkan gambar seri. Gambar seri adalah gambar yang memiliki pola urutan waktu atau urutan kejadian sesuai dengan peristiwa yang terjadi. Karangan yang memiliki ciri terdapat pola urutan waktu dan kejadian yaitu karangan narasi. Suparno dan Yunus (2008: 4.31) menyatakan bahwa karangan narasi adalah serangkaian kejadian menurut terjadinya (kronologis), dengan maksud memberi arti kepada serentetan kejadian, sehingga pembaca dapat memetik hikmah dari cerita itu. Narasi memiliki ciri yaitu adanya rangkaian peristiwa yang berurutan, sehingga dalam menulis narasi harus ada keterkaitan kejadian antar kalimat. Maka menulis narasi tidak mudah dan perlu disesuaikan alur, waktu, tempat dan kejadian dalam satu kesatuan.

Melalui wawancara dan pengamatan terhadap siswa yang dilakukan sebelumnya di Sekolah Dasar Negeri Mangkuyudan No. 02 Surakarta, ditemukan bahwa keterampilan menulis narasi di kelas III masih rendah. Siswa belum mampu menuliskan cerita narasi sesuai topik yang ditentukan. Hal ini dikarenakan, siswa kurang berminat terhadap pembelajaran yang melibatkan kegiatan menulis. Siswa juga mengalami kesulitan dalam mencari ide atau gagasan yang akan dituangkan dalam bentuk karangan narasi. Kebanyakan siswa beranggapan menulis narasi itu sulit, sehingga motivasi untuk menulis juga rendah. Permasalahan ini juga terjadi karena siswa kurang memperhatikan ketika guru sedang menyampaikan materi.

Berdasarkan hasil wawancara dengan guru kelas III SD Negeri Mangkuyudan No. 2 Surakarta, diperoleh informasi bahwa kemampuan siswa dalam menulis narasi termasuk rendah. Siswa belum mampu menuliskan ide berdasarkan gambar seri dalam bentuk karangan narasi. Hal ini juga dipengaruhi tingkat partisipasi dan keaktifan siswa masih rendah dalam menulis narasi. Dalam penyampaian materi tentang menulis narasi, guru kurang memberikan inovasi dalam penggunaan media 
pembelajaran. Media pembelajaran yang digunakan guru masih terbatas pada gambar yang ada dibuku siswa. Hal tersebut menyebabkan siswa mudah bosan. Oleh karena itu, dibutuhkan inovasi dalam pembelajaran dengan menggunakan model dan media pembelajaran yang dapat meningkatkan motivasi siswa untuk belajar.

Berdasarkan hasil observasi dan wawancara kemudian diperkuat dengan uji pratindakan menulis narasi terhadap siswa kelas III SD Negeri Mangkuyudan No. 02 Surakarta pada tanggal 11 Januari 2018, dapat diketahui bahwa terdapat 25 dari 27 siswa di kelas tersebut belum mencapai nilai Kriteria Ketuntasan Minimal (KKM). Pada hasil pratindakan menunjukkan bahwa skor tertinggi adalah 84 dan skor terendah 33 dengan rata-rata kelas 56,78. Nilai Kriteria Ketuntasan Minimal (KKM) yang telah ditentukan yaitu 70 dari 27 siswa, hanya 2 siswa $(7,4 \%)$ yang memenuhi $\mathrm{KKM}$, dengan nilai $\geq 70$, sedangkan 25 siswa (92,6\%) belum memenuhi Kriteria Ketuntasan Minimal (KKM) dengan nilai $<70$.

Berdasarkan hasil tersebut, diketahui bahwa keterampilan menulis siswa masih rendah terutama menulis karangan narasi. Rendahnya nilai pratindakan menulis siswa disebabkan ketidak runtutan rangkaian peristiwa, kurang sesuai antara judul dengan isi, pilihan kata kurang sesuai, serta ejaan dan tanda baca yang kurang tapat. Bila permasalahan tersebut tidak segera diatasi, maka dapat mengakibatkan siswa akan semakin kesulitan untuk menguasai keterampilan menulis, terutama menulis narasi berdasarkan gambar seri.

Berdasarkan beragam penyebab yang melatarbelakangi rendahnya keterampilan menulis siswa, maka penggunaan media yang inovatif sangat diperlukan dalam proses pembelajaran. Hal ini, bertujuan untuk menarik fokus dan perhatian siswa terhadap materi yang diajarkan. Salah satu alternatif untuk mengatasi permasalahan adalah penggunaan model pembelajaran Concept Sentence dengan berbantuan media gambar seri. Melalui model Concept Sentence dengan gambar seri diharapkan siswa dapat mengembangkan ide dan imajinasi melalui kata kunci yang disesuaikan dengan gambar seri yang disajikan lebih menarik.

Shoimin (2016: 37) mengemukakan bahwa model pembelajaran Concept Sentence adalah model pembelajaran yang dilakukan dengan memberikan kartu-kartu yang berisi beberapa kata kunci kepada siswa. Hal serupa disampaikan oleh Huda (2015: 315) yang menyatakan bahwa pembelajaran Concept Sentence ini dilakukan dengan memberikan kartu-kartu yang berisi beberapa kata kunci kepada siswa, kemudian kata kunci-kata kunci tersebut disusun menjadi beberapa kalimat dan dikembangkan menjadi paragraf-paragraf. Melalui penggunaan model pembelajaran Concept Sentence, siswa akan mudah menuangkan ide dalam sebuah tulisan karena model ini menyajikan kata-kata kunci yang sesuai dengan gambar seri. Kata-kata kunci tersebut, nantinya bisa dikembangkan siswa menjadi paragraf-paragraf, sehingga menjadi sebuah karangan.

Munirah (2017) berpendapat bahwa model pembelajaran Concept Sentence lebih diarahkan pada pembelajaran bahasa, terutama mempelajari sintaksis dengan menggunakan kata kunci. Model pembelajaran konsep kalimat menganggap siswa dalam kelompok heterogen. Karakterstik umum Concept Sentence adalah mempresentasikan kata-kata kunci. Penelitian ini menggunakan model Concept Sentence dengan gambar seri agar siswa lebih tertarik dalam pembelajaran menulis narasi. Menurut Murni (2016) gambar seri adalah sekumpulan gambar yang berisi 
kejadian, karakter dan setting narasi atau cerita. Gambar seri yang diberikan kata kunci dapat mempermudah siswa dalam mengembangkan kata kunci menjadi kalimat.

Shoimin (201: 38) mengemukakan langkah-langkah pelaksanaan model pembelajaran Concept Sentence, yaitu : (1) menyampaikan tujuan yaitu, guru menyampaikan tujuan kompetensi yang ingin dicapai; (2) menyajikan informasi yaitu, guru menyajikan materi secukupnya; (3) pembentukan kelompok yaitu, guru membentuk kelompok yang anggotanya sekitar 4 orang secara heterogen; (4) penyajian informasi kedua yaitu, guru menyajikan beberapa kata kunci sesuai materi yang disajikan; (5) tiap kelompok diarahkan membuat beberapa kalimat dengan menggunakan beberapa kata kunci yang diberikan; (6) hasil diskusi kelompok didiskusikan kembali secara pleno yang dipandu oleh guru; (7) guru menyimpulkan hasil pembelajaran. Model pembelajaran Concept Sentence dengan media gambar seri diterapkan karena mampu menjadikan siswa kreatif untuk mengembangkan kata kunci sesuai gambar seri menjadi kalimat narasi.

Berdasarkan latar belakang yang telah disampaikan di atas, rumusan masalah dalam penelitian ini adalah: (1) apakah penerapan model pembelajaran Concept Sentence dengan media gambar seri dapat meningkatkan keterampilan menulis narasi pada siswa kelas III SD Negeri Mangkuyudan No. 02 Surakarta tahun ajaran 2017/2018?; (2) bagaimana penerapan model pembelajaran Concept Sentence dengan media gambar seri yang dapat meningkatkan kualitas proses pembelajaran keterampilan menulis narasi pada siswa kelas III SD Negeri Mangkuyudan No. 02 Surakarta tahun ajaran 2017/2018?

Berdasarkan rumusan tersebut maka tujuan dari penelitian ini adalah (1) untuk meningkatkan keterampilan menulis narasi melalui model pembelajaran Concept Sentence dengan media gambar seri pada siswa kelas III SD Negeri Manguyudan No. 2 Surakarta tahun ajaran 2017/2018; (2) untuk mendeskripsikan kualitas proses pembelajaran keterampilan menulis narasi melalui model pembelajaran Concept Sentence dengan media gambar seri pada siswa kelas III SD Negeri Manguyudan No. 2 Surakarta tahun ajaran 2017/2018.

\section{METODE}

Penelitian ini dilaksanakan di SD Negeri Mangkuyudan No.02 Surakarta yang beralamat Jalan Kh. Samanhudi 34, Purwosari, Laweyan, Surakarta. Penelitian ini dilaksanakan selama lima bulan dari bulan Januari 2018 sampai dengan Mei 2018, pada tahun ajaran 2017/2018. Penelitian ini merupakan penelitian tindakan kelas yang dilaksanakan selama tiga siklus dengan tahapan perencanaan, pelaksanaan tindakan, observasi dan refleksi. Setiap siklus sebanyak dua pertemuan, sehingga penelitian ini dilaksanakan selama enam kali pertemuan. Subjek yang dituju pada penelitian ini adalah guru dan siswa kelas III SD Negeri Mangkuyudan No.02 Surakarta tahun ajaran 2017/2018 sejumlah 27 siswa dengan 12 siswa laki-laki dan 15 siswa perempuan.

Data yang diambil pada penelitian ini berupa data kualitatif dan data kuantitatif yang dikumpulkan dari sumber primer yaitu siswa dan guru kelas III SD Negeri Mangkuyudan No.02 Surakarta dan sumber sekunder yang diperoleh dari silabus dan dokumentasi kegiatan pembelajaran. Teknik yang digunakan untuk mengumpulkan data diantaranya adalah wawancara, pengamatan, kajian dokumen, dan tes. Kemudian data diuji validitasnya dengan menggunakan validitas isi, triangulasi sumber dan triangulasi teknik.

Teknik analisis data yang digunakan adalah teknik deskriptif komparatif dan model interaktif Miles dan Huberman. Teknik deskriptif komparatif digunakan untuk 
menganalisis data kuantitatif yang dilakukan dengan membandingkan nilai pada pratindakan, siklus I, siklus II dan siklus III. Sedangkan teknik analisis data yang digunakan untuk menganalisis data kualitatif adalah teknik analisis data model interaktif Miles dan Huberman dengan empat tahapan, yaitu pengumpulan data, reduksi data, penyajian data dan penarikan kesimpulan.

\section{HASIL DAN PEMBAHASAN}

Hasil penelitian ini menunjukkan adanya peningkatan keterampilan menulis narasi pada setiap siklusnya. Sebelum melaksanakan tindakan, peneliti melakukan kegiatan wawancara, observasi/pengamatan, dan memberikan tes pratindakan. Hasil tes pratindakan menunjukkan bahwa keterampilan menulis narasi siswa masih rendah. Pada siklus I, keterampilan menulis siswa juga masih rendah. Data perolehan nilai keterampilan menulis narasi siklus I pada siswa kelas III SD Negeri Mangkuyudan No.02 Surakarta dapat dilihat pada Tabel 2. Sebagai berikut:

Tabel 1. Distribusi Frekuensi Nilai Keterampilan Menulis Narasi Siklus I

\begin{tabular}{|c|c|c|c|c|c|c|}
\hline \multirow[t]{2}{*}{ No. } & \multirow[t]{2}{*}{ Interval Nilai } & \multirow{2}{*}{$\begin{array}{c}\text { Frekuensi } \\
\text { (fi) }\end{array}$} & \multirow{2}{*}{$\begin{array}{l}\text { Median } \\
\text { (xi) }\end{array}$} & \multirow[t]{2}{*}{ fi.xi } & \multicolumn{2}{|c|}{ Persentase \% } \\
\hline & & & & & Relatif & $\underset{f}{\text { Komulati }}$ \\
\hline 1. & $42-48$ & 2 & 45 & 90 & 7,41 & 7,41 \\
\hline 2. & $49-55$ & 11 & 52 & 572 & 40,74 & 48,15 \\
\hline 3. & $56-62$ & 5 & 59 & 295 & 18,52 & 66,67 \\
\hline 4. & $63-69$ & 4 & 66 & 264 & 14,81 & 81,48 \\
\hline 5. & $70-76$ & 3 & 73 & 219 & 11,11 & 92,59 \\
\hline 6. & $\begin{array}{l}\text { 77- } 83 \\
\text { Jumlah }\end{array}$ & $\begin{array}{c}2 \\
27\end{array}$ & 80 & $\begin{array}{c}160 \\
1600\end{array}$ & $\begin{array}{l}7,41 \\
100\end{array}$ & 100 \\
\hline \multicolumn{7}{|c|}{$\begin{array}{c}\text { Rata-rata }=59,26 \\
\text { Nilai Tertinggi }=78 \\
\text { Nilai Terendah }=42,5 \\
\text { Ketuntasan Klasikal }=18,52 \%\end{array}$} \\
\hline
\end{tabular}

Berdasarkan Tabel 1, dari 27 siswa di kelas III, hanya terdapat 5 siswa yang memperoleh nilai KKM 70, atau setara dengan $18,52 \%$ dari jumlah siswa, sedangkan 22 siswa atau 81,48\% siswa masih memperoleh nilai di bawah KKM dengan nilai ratarata 59,26. Setelah diterapkan model concept sentence dengan media gambar seri dalam pembelajaran, keterampilan menulis narasi siswa mengalami peningkatan. Data perolehan nilai keterampilan menulis narasi siswa siklus II siswa kelas III SD Negeri Mangkuyudan No.02 Surakarta dapat dilihat pada Tabel 2.

Tabel 2. Distribusi Frekuensi Nilai Keterampilan Menulis Narasi pada Siklus II

\begin{tabular}{|c|c|c|c|c|c|c|}
\hline No. & Interval Nilai & Frekuensi (fi) & Median & fi.xi & Per & tase \% \\
\hline 1. & & & $(x i)$ & & Relatif & Komulatif \\
\hline 2. & $56-62$ & 3 & 59 & 177 & 11,11 & 11,11 \\
\hline 3. & $63-69$ & 8 & 66 & 528 & 29,63 & 40,74 \\
\hline 4. & $70-76$ & 8 & 73 & 584 & 29,63 & 70,37 \\
\hline 5. & $77-83$ & 5 & 80 & 400 & 18,52 & 88,89 \\
\hline 6. & $84-90$ & 3 & 87 & 261 & 11,11 & 100 \\
\hline & Jumlah & 27 & & 1950 & 100 & \\
\hline \multicolumn{7}{|c|}{$\begin{aligned} \text { Rata-rata } & =72,22 \\
\text { Nilai Tertinggi } & =90 \\
\text { Nilai Terendah } & =57 \\
\text { Ketuntasan Klasikal } & =59,26 \%\end{aligned}$} \\
\hline
\end{tabular}


Melihat Tabel 2, dapat diketahui bahwa nilai ketuntasan siswa kelas III pada saat siklus II sejumlah 16 atau 59,26\% siswa tuntas KKM sedangkan 11 atau 40,74\% siswa tidak tuntas KKM dengan nilai rata-rata 72,77. Nilai keterampilan menulis narasi siswa kelas III SD Negeri Mangkuyudan No.02 Surkarta pada siklus II menunjukkan adanya peningkatan jika dibandingkan dengan nilai saat siklus I, namun dari hasil tersebut belum mencapai target pada indikator pencapaian yang telah ditetapkan yaitu $80 \%$ siswa memperoleh nilai $\geq 70$ sehingga perlu direfleksi dan dapat ditindaklanjuti pada siklus III. Setelah dilakukan tindakan siklus III ditemukan adanya peningkatan nilai keterampilan menulis narasi dari hasil sebelumnya, hasil penelitian pada siklus III dapat dilihat pada Tabel 3.

\begin{tabular}{|c|c|c|c|c|c|c|}
\hline \multirow{2}{*}{$\begin{array}{l}\text { No. } \\
1 .\end{array}$} & \multirow[t]{2}{*}{ Interval Nilai } & \multirow{2}{*}{$\begin{array}{l}\text { Frekuensi } \\
\text { (fi) }\end{array}$} & \multirow{2}{*}{$\begin{array}{c}\text { Median } \\
\text { (xi) }\end{array}$} & \multirow[t]{2}{*}{ fi.xi } & \multicolumn{2}{|c|}{ Presentase \% } \\
\hline & & & & & Relatif & Komulatif \\
\hline 2. & $64-69$ & 1 & 66,5 & 66,5 & 3,71 & 3,71 \\
\hline 3. & $70-75$ & 5 & 72,5 & 362,5 & 18,52 & 22,23 \\
\hline 4. & $76-81$ & 5 & 78,5 & 392,5 & 18,52 & 40,75 \\
\hline 5. & $82-87$ & 8 & 84,5 & 676 & 29,62 & 70,37 \\
\hline 6. & $88-93$ & 5 & 90,5 & 452,5 & 18,52 & 88,89 \\
\hline 7. & $94-99$ & 3 & 96,5 & 289,5 & 11,11 & 100 \\
\hline & Jumlah & 27 & & 2239,5 & 100 & \\
\hline \multicolumn{7}{|c|}{$\begin{aligned} \text { Rata-rata } & =82,94 \\
\text { Nilai Tertinggi } & =96 \\
\text { Nilai Terendah } & =66 \\
\text { Ketuntasan Klasikal } & =96,29 \%\end{aligned}$} \\
\hline
\end{tabular}

Hasil tindakan pada siklus III menunjukkan bahwa nilai ketuntasan siswa kelas III adalah 96,29\% atau sejumlah 26 siswa memperoleh nilai KKM 70, sedangkan 1 siswa lainnya atau $3,71 \%$ tidak tuntas KKM. Indikator kinerja berhasil tercapai sehingga penelitian tindakan kelas peningkatan keterampilan menulis narasi pada siswa kelas III SD Negeri Mangkuyudan No.02 Surakarta dihentikan pada siklus III.

Pengukuran nilai keterampilan menulis narasi diperoleh hasil bahwa nilai siswa mengalami peningkatan. Perbandingan nilai keterampilan menulis narasi pada siswa saat siklus I, siklus II dan siklus III dapat dilihat pada tabel 4.

Tabel 4. Perbandingan Nilai

\begin{tabular}{lccc}
\hline \multicolumn{1}{c}{ Keterangan } & Siklus I & Siklus II & Siklus III \\
\hline Nilai Terendah & 42,5 & 57 & 66 \\
Nilai Tertinggi & 78 & 90 & 96 \\
Nilai Rata-rata & 59,26 & 72,22 & 82,94 \\
Ketuntasan & $22,22 \%$ & $59,26 \%$ & $96,29 \%$ \\
Klasikal(\%) & & & \\
\hline
\end{tabular}

Penerapan model pembelajaran Concept Sentence pada siklus I berhasil meningkatkan nilai rata-rata keterampilan menulis narasi siswa yaitu sebesar 59,26. Persentase ketuntasan belum mencapai indikator kinerja penelitian. Indikator kinerja penelitian keterampilan menulis narasi dalam penelitian ini sebesar $80 \%$ siswa mendapat nilai KKM $\geq 70$. Hambatan yang terjadi pada siklus I yakni guru belum terampil dalam membimbing siswa untuk melakukan langkah-langkah model pembelajaran Concept Sentence untuk meningkatkan keterampilan menulis narasi. Selain itu, beberapa siswa belum memperhatikan penjelasan dari guru. Akibatnya nilai 
keterampilan keterampilan menulis narasi siswa belum maksimal. Oleh karena itu, peneliti dan guru melanjutkan tindakan siklus II untuk memperbaiki tindakan pada siklus I. Perbaikan dilakukan pada kualitas proses pembelajaran. Serta guru memotivasi siswa agar lebih bersemangat dan fokus dalam pembelajaran.

Peningkatan pada siklus II ketuntasan klasikal dan nilai rata-rata keterampilan menulis narasi siswa meningkat, namun belum mencapai indiakator kinerja penelitian. Hambatan dalam siklus II adalah siswa siswa belum bersungguh-sungguh dalam melakukan langkah-langkah pembelajaran Concept Sentence dengan media gambar seri sehingga siswa kurang memahami kegiatan yang siswa lakukan. Oleh karena itu, peneliti bersama guru melanjutkan tindakan siklus III untuk memperbaiki tindakan pada siklus II.

Peningkatan pada siklus III yaitu pada nilai rata-rata keterampilan menulis narasi siswa. Persentase ketuntasan klasikal juga meningkat dan berhasil mencapai $80 \%$ sehingga telah mencapai indikator kinerja yang ditetapkan. Berdasarkan hasil siklus III, masih ada 1 siswa $(3,71 \%)$ yang belum belum tuntas KKM $(\geq 70)$. Penyebab siswa tersebut tidak tuntas yaitu penggunaan kosakata bahasa yang kurang tepat dan kurang memperhatikan penggunaan ejaan dan tanda baca yang benar dalam menulis narasi. Meskipun terdapat 1 siswa yang belum tuntas, penelitian tidak dilanjutkan ke siklus berikutnya karena telah mencapai indikator kinerja yang telah ditetapkan. Selanjutnya, 1 siswa yang belum tuntas tersebut peneliti kembalikan kepada guru kelas III agar dibimbing kembali mengenai penggunaan kosakata, ejaan, dan tanda baca yang benar.

Berdasarkan uraian tersebut, menunjukkan penggunaan model pembelajaran Concept Sentence dengan media gambar seri cocok digunakan untuk meningkatkan pembelajaran keterampilan menulis narasi. Model pembelajaran Concept Sentence dengan media gambar seri memudahkan siswa mengembangkan ide dalam menulis narasi melalui penggunaan kata kunci yang disesuaikan dengan gambar. Hal itu sesuai pendapat Kurniasih dan Sani (2016: 104) bahwa Concept Sentence merupakan salah satu teknik dari Cooperative Learning, dimana siswa belajar dengan kelompoknya untuk membuat beberapa kalimat sesuai dengan kata kunci yang telah diberikan guru kepada siswa. Sehingga model pembelajaran Concept Sentence dengan media gambar seri cocok digunakan dalam pembelajaran Bahasa Indonesia materi menulis narasi kelas III yang menekankan pada kegiatan kelompok secara heterogen melalui penggunaan kata kunci dan gambar seri yang dapat meningkatkan kreativitas dan partisipasi siswa.

Hasil penelitian ini sesuai dengan hasil penelitian yang dilakukan oleh Anton Sugiyarto (2016) dalam skripsi dengan judul "Penggunaan Model Pembelajaran Kooperatif Tipe Concept Sentence untuk Meningkatkan Keterampilan Menulis Cerita Kembali pada Peserta Didik Kelas IV SD Negeri Gumpang 3 Sukoharjo Tahun Ajaran 2015/2016". Hasil penelitian ini menunjukkan bahwa penggunaan model Concept Sentence dapat meningkatkan keterampilan menulis cerita kembali pada siswa kelas IV SD Negeri Gumpang 3 Sukoharjo tahun ajaran 2015/2016 yang ditandai dengan meningkatnya ketuntasan klasikal siswa pratindakan sebesar $13 \%$, pada siklus 1 sebesar $56,5 \%$, dan pada siklus 2 sebesar $82,5 \%$.

Berdasarkan hasil penelitian tersebut, maka hasil penelitian ini juga menunjukan bahwa terjadi peningkatan keterampilan menulis narasi pada siswa kelas III SD Negeri Mangkuyudan No.02 Surakarta. Hal tersebut dapat dilihat dari nilai rata-rata kelas dari pratindakan yaitu 56. Penerapan model pembelajaran Concept Sentence dengan media gambar seri pada siklus I dapat meningkat menjadi 59,26 dan di siklus II rata- 
rata meningkat menjadi 72,22 , serta pada siklus III rata-rata meningkat menjadi 82,94. Berdasarkan hasil analisis data dan pembahasan tersebut di atas, jika dikaitkan dengan penelitian yang dilakukan Anton Sugiyarto (2016) maka dapat disimpulkan bahwa dengan menerapkan model pembelajaran kooperatif tipe Concept Sentence dengan media gambar seri dalam pembelajaran Bahasa Indonesia dapat meningkatkan keterampilan menulis narasi pada siswa kelas III SD Negeri Mangkuyudan No.02 Surakarta tahun ajaran 2017/2018.

\section{SIMPULAN}

Berdasarkan hasil penelitian tindakan kelas yang telah dilaksanakan selama tiga siklus yang setiap siklusnya terdiri dari dua pertemuan dapat ditarik simpulan bahwa melalui penerapan model pembelajaran Concept Sentence dengan media gambar seri dapat meningkatkan keterampilan menulis narasi pada siswa kelas III SD Negeri Mangkuyudan No.02 Surakarta ajaran 2017/2018. Peningkatan tersebut dibuktikan dengan meningkatnya nilai keterampilan menulis narasi siswa pada pembelajaran Bahasa Indonesia materi menulis karangan sederhana pada setiap pertemuannya. Hasil penelitian ini dapat digunakan guru untuk memilih model dan media pembelajaran yang tepat agar dapat meningkatkan kualitas pembelajaran,serta dikembangkan oleh guru untuk mengatasi masalah sejenis yang umumnya dihadapi siswa.

\section{DAFTAR PUSTAKA}

Dalman, H. (2016). Keterampilan Menulis. Jakarta: PT Raja Grafindo Persada.

Huda, Miftahul. (2013). Model-Model Pengajaran dan Pembelajaran. Malang: Pustaka Pelajar.

Kurniasih, I. \& Sani, B. (2016). Ragam Pengembangan Model Pembelajaran: untuk Peningkatan Profesional Guru. Jakarta: Kata Pena.

Munirah, (2017). The Effectiveness of Concept Sentence Model toward Writing Skill of Persuasive Paragraph Volume 7, Number 2. International Journal of Theory and Practice in Language Studies Universitas Muhammadiyah Makasar.

Murni, F. AR. (2016). Using Picture Series Enchances Students' Ability In Writing Narrative. Proceeding International Seminar on Education Faculty of Tarbiyah and Teacher Training. IAIN Batu Sangkar Padang.

Shoimin, (2016). 68 Model Pembelajaran Inovatif dalam Kurikulum 2013. Yogyakarta: Ar-Ruzz Media.

Suparno \& Yunus, M. (2008). Keterampilan Menulis. Jakarta: Universitas Terbuka. 